

\section{VOL. XVII.-1902.}

THE

\section{JOURNAL OF LARYNGOLOGY,}

\section{RHINOLOGY, AND OTOLOGY;}

AN ANALYTICAL RECORD OF CURRENT LITERATURE

RELATING TO

\section{THE THROAT, NOSE, AND EAR.}

PUBLISHED MONTHLY.

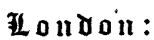

REBMAN, LIMITED, 129, Shaftesbury Avenue, Cambridge Circus, W.C: 


\section{THE JOURNAL OF LARYNGOLOGY RHINOLOGY, AND OTOLOGY.}

Founded in 1887 by MORELL MACKENZIE and NORRIS WOLFENDEN.

EDITORS :

JOHN MACINTYRE, M.B., M.Ch., F.R.S.E.

DUNDAS GRANT, M.A., M.D., F.R.C.S. Eng.

ARTHUR SANDFORD, M.D., M.Ch.R.U.I.

R. LAKE, F.R.C.S.

W. MILLIGAN, M.D., Sub-Editor.

W. JOBSON HORNE, M.A., M.D.; B.C.Cantab., M.R.C.P. Lond., Managing Sub-Editor.

WITH THE CO-OPERATION OF

Drs. Baron (Bristol), Prick-Brown (Toronto), Cartaz (Paris),

Bryson Drlavan (New York), Dond (Chicago), Donklan (London),

Grazzi (Florence), GuYe (Amsterdam), HigGuet (Brusselss),

Mrodlemass Hunt (Liverpool), Hutohison (Brighton), Joal (Paris),

Kelly (Glasgow), Lacoarret (Toulouse), Liohtwitz (Bordeaux),

Lieven (Aix-la-Chapelle), John N. Mackenzie (Baltimore), Prot. Massei (Naples),

Mryues (Amsterdam), Mrles (New York), Holakr Mrgind (Copenhagen),

Porter (St. Louis), Guild (Dundee), Sachs (Hamlnurg),

StGeorge Reid (London). Sajous (Philadelphia), Skxtzzík (Warsaw),

Sota (Seville), StClair Thomson (London), Waggett (London),

Woods (Duhlin), and Zrem (Dantzic). 


\section{LIST OF PLATES.}

Portrait of the late Dr. Achille Gouguenheim To face p. 1

Plates I., II., III., IV., V.-To illustrate Dr. Christian R. Holmes' Paper on Enormous Naso-Pharyngeal Soft Fibroma - - - - - To face pp. 400, 402, 410

Plates I., II., III.-To illustrate Dr. John Macintyre's Paper on the Diagnosis and Treatment of Foreign Bodies in the Upper Air Passages and Gullet

To face $p p .470,472,474$

Plates I.-VIII.-To illustrate Dr. Gustay Killian's Paper on Short Hints for Examining the Esophagus, Trachea, and Bronchi by Direct Methods - To face pp. 505, 506, 508

Portrait of the late Mr. Lennox Browne - To face p. 629 


\section{CONTENTS.}

Special Articles- $\quad$ PAGK

The Treatment of Middle-Ear Suppuration.-Richand ARTHUn ... .. 225

A Case of Neurasthenic Nerve-Deafness._Dundas Graxt $\quad \ldots \quad$.. 234

\section{Societies' Proceedings-}

The British laryigological, Rhinological, and Otological Associa-

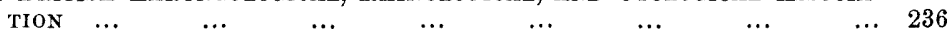

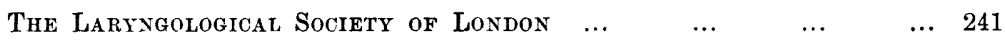

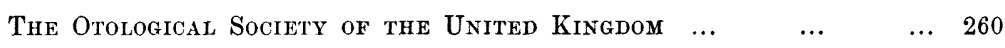

\section{Abstracts--}

Mocth, Favces, Etc. - The Pathogenesis of Lacunar Keratosis of the Tonsil 274

Nose ANd NAso-Pharynx.-Cyst of Right Nasal Passage-Treatment of
Lupus of the Ear and Nose by Hot Air ...
$\begin{array}{llll}\ldots & \ldots & \ldots & 279\end{array}$

LARYxX. - A Burn of the Larynx caused by a Dupuytren's Pill $\quad \ldots \quad 279$

EAR.-The Microscope as an Aid to Diagnosis and Prognosis in Chronic

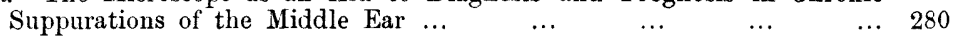

\section{New Preparation-}

"Tabloid" Apomorphine Compound.-Burrovghs Wellcome axd Co. ... 280

\section{GUIDE TO ADVERTISEMENTS.}

\begin{tabular}{llllllr} 
Burroughs Wellcome \& Co. & $\ldots$ & $\ldots$ & $\ldots$ & $\ldots$ & PAGE. \\
Fowler's "Invisible Respirator " & $\ldots$ & $\ldots$ & $\ldots$ & $\ldots$ & iii \\
Golden Square Throat Hospital & $\ldots$ & $\ldots$ & $\ldots$ & $\ldots$ & x \\
Henry Heil Chemical Co. $\ldots$ & $\ldots$ & $\ldots$ & $\ldots$ & $\ldots$ & iv \\
Ingram \& Royle ... & $\ldots$ & $\ldots$ & $\ldots$ & $\ldots$ & $\ldots$ & vii \\
Lambert Pharmacal Co. & $\ldots$ & $\ldots$ & $\ldots$ & $\ldots$ & $\ldots$ & ii \\
Maw, Son \& Sons & $\ldots$ & $\ldots$ & $\ldots$ & $\ldots$ & $\ldots$ & ii \\
Mayer \& Meltzer ... & $\ldots$ & $\ldots$ & $\ldots$ & $\ldots$ & $\ldots$ & ix, xi \\
Metropolitan Ear, Nose and Throat Hospital & $\ldots$ & $\ldots$ & xii \\
Nelson, Dale \& Co., Ltd. & $\ldots$ & $\ldots$ & $\ldots$ & $\ldots$ & $\ldots$ & viii \\
Parke, Davis \& Co. & $\ldots$ & $\ldots$ & $\ldots$ & \multicolumn{2}{c}{ Front page of cover } \\
Rebman, Limited & $\ldots$ & $\ldots$ & $\ldots$ & $\ldots$ & iii, iv, vii, viii \\
\end{tabular}



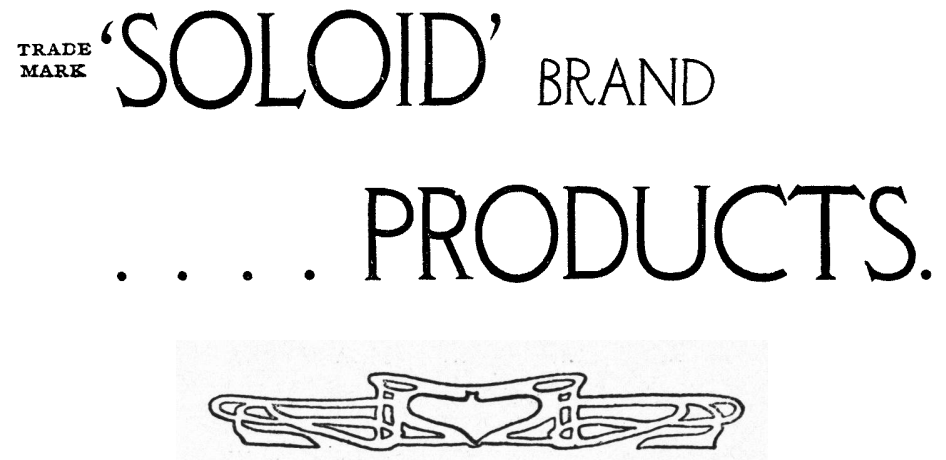

'Soloid' Brand Products provide the practitioner with portable and reliable antiseptics, astringents, anaesthetics, etc., and with convenient and accurate means of preparing stains for microscopic work and test solutions for the analysis of water or urine.

\section{'SOLOID' Brand}

, Carbolic Acid

", Cocaine Hydrochlor.

„Cocaine and Eucaine

"Corrosive Sublimate

, Eucaine Hydrochlor.

, Lead ana Opium

„, Lead Subacetate

, Mercuric Potassium Iodide (Iodic Hydrarg.)

, Potassium Permang.

,"Zinc Sulphate etc., etc., etc.

For full lists and particulars see WeLicome's MEdiCAL Diary. AVOID IMITATIONS.

Burroughs Wellcome and Co., London And Sydney. 